\title{
Influence of Nutrient Supplementation on Torulaspora Delbrueckii Wine Fermentation Aroma
}

\author{
Debora Mecca ${ }^{1}$, Santiago Benito ${ }^{2, *(\mathbb{D})}$, Beata Beisert ${ }^{1}$, Silvia Brezina ${ }^{1}$, Stefanie Fritsch ${ }^{1}$, \\ Heike Semmler ${ }^{1}$ and Doris Rauhut ${ }^{1}$ \\ 1 Department of Microbiology and Biochemistry, Hochschule Geisenheim University (HGU), \\ Von-Lade-Straße 1, 65366 Geisenheim, Germany; Debora.Mecca@hs-gm.de (D.M.); \\ Beata.Beisert@hs-gm.de (B.B.); Silvia.Brezina@hs-gm.de (S.B.); Stefanie.Fritsch@hs-gm.de (S.F.); \\ Heike.Semmler@hs-gm.de (H.S.); doris.rauhut@hs-gm.de (D.R.) \\ 2 Department of Food Chemistry and Technology, Polytechnic University of Madrid, \\ Ciudad Universitaria S/N, 28040 Madrid, Spain \\ * Correspondence: santiago.benito@upm.es; Tel.: +34-913363710 or +34-913363984
}

Received: 15 February 2020; Accepted: 19 March 2020; Published: 22 March 2020

\begin{abstract}
This study was performed with the aim of characterizing the fermentative performance of three commercial strains of Torulaspora delbrueckii and their impact on the production of volatile and non-volatile compounds. Laboratory-scale single culture fermentations were performed using a commercial white grape juice. The addition of commercial nutrient products enabled us to test the yeasts under two different nutrient conditions. The addition of nutrients promoted fermentation intensity from $9 \%$ to $20 \%$ with significant differences $(p<0.05)$ among the strains tested. The strain diversity together with the nutrient availability influenced the production of volatile compounds.
\end{abstract}

Keywords: Torulaspora delbrueckii; volatile compounds; nutrients

\section{Introduction}

In the last few decades, several researchers have focused on characterizing the oenological potential of non-Saccharomyces yeasts [1-3]. Non-Saccharomyces species can contribute substantially to the quality of wines. Some yeast species can enhance and modulate the production of volatile aroma compounds thanks to specific enzymatic properties [4-8]. Others promote the production of glycerol, the reduction of acetic acid, and the release of mannoproteins, as well as contributing to color stabilization [9-12]. Detailed and extensive knowledge of the properties of these yeasts will ensure targeted use in order to achieve the desired wine quality and style.

Torulaspora delbrueckii is a ubiquitous yeast species frequently found in association with human activity and food processing. In particular, it has been found in close association with wine, beer, and bread $[13,14]$. T. delbrueckii was one of the first non-Saccharomyces yeasts to draw the attention of industrial producers of starter cultures and to be commercially available as active dry yeast, first as a component of different yeast blends and then in pure formulation $[1,15,16]$. Nowadays, the most popular dry yeast manufacturers have T. delbrueckii available in their catalogues [14,16].

After the first discoveries of T. delbrueckii in association with fermenting must, different research groups started investigating its oenological potential. Some studies comprehensively characterized the genetic diversity within T. delbrueckii strains focusing on its application in winemaking [17,18]. The high variability registered among different strains of T. delbrueckii [6,19] demonstrates the high genetic diversity that characterizes this species. It has been demonstrated that this genetic diversity is the result of a long process of domestication under the most diverse conditions in wine production 
environments [13]. The availability of such high genetic diversity is very important and means that there is still an opportunity to search for improved characteristics.

Many studies have investigated the influence of $T$. delbrueckii under different fermentation conditions, using different inoculation strategies, for the production of red, white, and sparkling wines [20]. T. delbrueckii often shows a slower fermentation rate than S. cerevisiae; many studies reported longer fermentation durations and a longer lag phase, with wines frequently containing an unacceptable residual sugar content for dry wines [21,22]. T. delbrueckii was demonstrated to produce lower amounts of acetaldehyde and acetic acid in comparison with S. cerevisiae, confirming its high potential for application in wine production $[9,22]$. Regarding the production of glycerol, results from the literature are contradictory, showing sometimes higher $[9,17,23]$ and sometimes lower production of glycerol than S. cerevisiae [24]. With respect to organic acids, and apart from acetic acid production, T. delbrueckii also demonstrated a certain activity of malic acid degradation, higher than the usual levels reported for S. cerevisiae $[21,22,25,26]$. T. delbrueckii is generally regarded as a low producer of aroma compounds; studies have reported an average production of higher alcohols of about $100 \mathrm{mg} / \mathrm{L}$ [17] and a lower production of esters than $S$. cerevisiae $[4,17,26-28]$. Confirmation of these findings comes from a demonstration of the low enzymatic activity of esterases in T. delbrueckii [6]. On the other hand, studies have reported slight activity of T. delbrueckii toward monoterpenes [29,30] and the precursors of volatile thiols $[25,31,32]$ and therefore its ability to modulate the aroma profile of wines from grape varieties such as those from the Muscat family or Gewürztraminer, but also Sauvignon blanc, Riesling, or Verdejo [8].

The aim of this work was to compare the fermentation performance and aroma compound production of three commercial yeast strains of $T$. delbrueckii during the fermentation of a white grape juice under two different nutrient conditions.

\section{Materials and Method}

\subsection{Yeast Strains}

All fermentations were conducted with commercially available Torulaspora delbrueckii strains: Viniflora ${ }$ Prelude $^{\mathrm{TM}}$ (Hansen, Hørsholm, Denmark), Biodiva ${ }^{\mathrm{TM}}$ TD291 (Lallemand, Montreal, Canada), and Zymaflore $®$ Alpha TD n. Sacch (Laffort, Bordeaux, France) (hereafter Prelude, Biodiva, and AlphaTd).

\subsection{Juice Composition}

A commercial white grape juice (Jacoby GmbH, Germany; http://www.jacoby.de/index.php/en/ produkte?page=shop.product_details\&flypage=flypage.tpl\&product_id=47\&category_id=83) was used to perform laboratory-scale fermentations. D-glucose and D-fructose were both added at a concentration of $10 \mathrm{~g} / \mathrm{L}$. The total amount of sugars in the juice after the addition was $168.9 \mathrm{~g} / \mathrm{L}$. The fermentations were performed under 2 nutrient conditions for each strain tested: (1) no addition of nutrients and (2) addition of 2 nutrients. Two commercial products by the Lallemand company (Montreal, Canada), Fermaid®E-blanc and OptiMUM white ${ }^{\mathrm{TM}}$, were used at a concentration of $0.4 \mathrm{~g} / \mathrm{L}$ to provide nutrients. In the juice without the addition of nutrients, the concentration of ammonium was $81 \mathrm{mg} / \mathrm{L}$ and the primary amino nitrogen (NOPA) value was $118 \mathrm{mg} \mathrm{N} / \mathrm{L}$. The total yeast assimilable nitrogen content of the juice after the addition of nutrient preparations was $281 \mathrm{mg} \mathrm{N} / \mathrm{L}$, corresponding to a NOPA value of $137 \mathrm{mg} \mathrm{N} / \mathrm{L}$ and an ammonium content of $144 \mathrm{mg} \mathrm{N} / \mathrm{L}$. The initial acid content was as follows: tartaric acid $2.33 \mathrm{~g} / \mathrm{L}$, malic acid $2.18 \mathrm{~g} / \mathrm{L}$, citric acid $0.11 \mathrm{~g} / \mathrm{L}$, lactic acid $<0.1 \mathrm{~g} / \mathrm{L}$, and acetic acid $<0.1 \mathrm{~g} / \mathrm{L}$. Primary amino nitrogen and ammonium concentrations were determined using an Evolution ${ }^{\mathrm{TM}} 220$ spectrophotometer (Thermo Fisher Scientific, Darmstadt, Germany) and the commercial enzymatic kits K-PANOPA (Megazyme-Romer Labs, Bulzbach, Germany) and K-AMIAR (Megazyme-Romer Labs, Bulzbach, Germany) following the instructions of the manufacturer. 


\subsection{Microvinifications}

All fermentations were conducted in $500 \mathrm{~mL}$ Schott-Duran ${ }^{\circledR}$ bottles following a previous protocol but adapted to the scale [33,34]. Each variant was performed in triplicate. All operations took place under aseptic conditions to avoid any contamination. According to the specifications of the protocol [33], $0.5 \mathrm{~L}$ of must sterilized $\left(115^{\circ} \mathrm{C}, 15 \mathrm{~min}\right)$ after nutrient and sugar correction were placed in a $1 \mathrm{~L}$ glass fermentation flask, leaving enough space for carbon dioxide emission. All inoculations were performed in $1 \mathrm{~L}$ flasks sealed with a fermentation lock filled with $98 \% \mathrm{H}_{2} \mathrm{SO}_{4}$ (Sigma-Aldrich, San Luis, USA), which allowed the release of $\mathrm{CO}_{2}$ while avoiding microbial contamination. Three non-inoculated flasks were used to verify the success of the sterilization and aseptic conditions, as they did not ferment during the study. The volume of inoculum was $10 \mathrm{~mL}$ in each bottle. The inoculum was prepared by rehydrating $100 \mathrm{mg}$ of the corresponding commercial strain product in $10 \mathrm{~mL}$ of sterilized water under laboratory sterile conditions. The number of cells was evaluated by cell counting using a Thoma counting chamber Blaubrand ${ }^{\circledR}$ (Brand, Wertheim, Germany) in a Leica DM 500 microscope (Wetzlar, Germany). The final concentration of inoculated cells in $500 \mathrm{~mL}$ was $0.5 \times 10^{7} \mathrm{cfu}$ for Prelude samples, $1.2 \times 10^{7} \mathrm{cfu}$ for Biodiva samples, and $3.8 \times 10^{7} \mathrm{cfu}$ for AlphaTd samples. The bottles were closed with fermentation lockers previously filled with a solution of water and potassium metabisulfite at a concentration of $50 \mathrm{~g} / \mathrm{L}$ to avoid contamination. The fermentations were carried out in an incubator at a controlled temperature of $25^{\circ} \mathrm{C}$ for 15 days. The progress of the fermentations was followed by daily measurements of flask weights. On the 15 th day, all bottles were moved to a refrigerator room at $4{ }^{\circ} \mathrm{C}$ for 8 days. stopping the alcoholic fermentation and settling down the wine, then the wine was racked. Under aseptic conditions, sterilized glass bottles were filled and closed with screw caps after the addition of a solution of potassium metabisulfite at a final concentration of $80 \mathrm{mg} / \mathrm{L}$. The wines were kept refrigerated at $4{ }^{\circ} \mathrm{C}$ until the chemical analyses were performed.

\subsection{HPLC Analyses}

The main oenological parameters of juice before fermentation were measured by means of high-performance liquid-liquid chromatography (HPLC) based on a previously reported methodology [35] with the following modifications [34]. Samples were prepared in $1.5 \mathrm{~mL}$ vials after centrifugation at $13,000 \mathrm{rpm}$ for $5 \mathrm{~min}$ and subsequent dilution to 1:1 with distilled water, and $5 \mu \mathrm{L}$ was successively injected into an Agilent Technologies 1100 series liquid chromatograph (Agilent Technologies GmbH, Germany) equipped with 2 detectors, a multi-wavelength detector, and a refractive index (RI) detector (Agilent Technologies GmbH, Germany). Eluting compounds were detected by UV absorbance at $210 \mathrm{~nm}$ by the multi-wavelength detector. The samples were analyzed using an Allure Organic Acid Column ( $250 \mathrm{~mm} \times 4.6 \mathrm{~mm}$ inside diameter, $5 \mu \mathrm{m}$ particle size, $60 \mathrm{~A}^{\circ}$ pore size) from Restek $\mathrm{GmbH}$ (Bad Homburg, Germany) with a C-18 Security Guard Cartridge, $4.0 \times 3.0 \mathrm{~mm}$ (Phenomenex GmbH, Aschaffenburg, Germany). The column temperature was set at $46^{\circ} \mathrm{C}$; the eluent consisted of distilled water with $0.0139 \%$ sulfuric acid and $0.5 \%$ ethanol (flow rate: $0.6 \mathrm{~mL} / \mathrm{min}$ ). For quantitative analysis of each compound, external standards of organic acids, sugars, and ethanol were used. The concentration of glycerol was determined with the same procedure but at a temperature of $29^{\circ} \mathrm{C}$.

\subsection{Wine Composition}

The concentration of low-volatile sulfur compounds was evaluated in the final wines by means of a headspace gas chromatograph (6890, Agilent Technologies, Germany) using a pulsed flame photometric detector (HS-GC-PFPD), according to the methodology described in a previous study [36]. The analysis was carried out as follows: $5 \mathrm{~mL}$ of sample at $4{ }^{\circ} \mathrm{C}$ was placed in a $10 \mathrm{~mL}$ headspace vial containing $1.7 \mathrm{~g}$ of $\mathrm{NaCl}$ and flushed with argon, which replaces oxygen and prevents the occurrence of oxidation reactions. As internal standards, methyl-iso-propyl sulphide and butyl methyl sulphide were used. The other reagents were $4 \mathrm{mg} / \mathrm{L}$ of 2,6-di-tert-butyl-4-methyl-phenol (antioxidant), $0.2 \mathrm{~g} / \mathrm{L}$ of ethylene diamine tetraacetic acid (EDTA; chelating agent), and $500 \mathrm{mg} / \mathrm{L}$ of propanal (added to 
bind $\mathrm{SO}_{2}$ ). The procedure started with preheating the samples to $60^{\circ} \mathrm{C}$ for 45 min under constant agitation, and then the headspace sampler (MPS 2 MultiPurpose Sampler, Gerstel, Mülheim an der Ruhr, Germany) injected $1 \mathrm{~mL}$ of the headspace into the cooled injection system (CIS 4, Gerstel, Mülheim an der Ruhr, Germany). The injection system operated with the following temperature program: first, a cooling step to $-100{ }^{\circ} \mathrm{C}$, then heating to $40{ }^{\circ} \mathrm{C}$ at a rate of $12{ }^{\circ} \mathrm{C} / \mathrm{s}$ and held for $1 \mathrm{~min}$, and finally, heating to $180^{\circ} \mathrm{C}$ and held for $8 \mathrm{~min}$. Subsequently, the analytes were moved to the column in 10:1 split mode. The column was an SPB-1 sulfur capillary column $(30 \mathrm{~m} \times 0.32 \mathrm{~mm}$ I.D., $4 \mu \mathrm{m}$ film thickness; Supelco, Darmstadt, Germany). The temperature program of the column was as follows: $7 \mathrm{~min}$ at $29^{\circ} \mathrm{C}$, then $10.5 \mathrm{~min}$ at $180^{\circ} \mathrm{C}$, heating at a rate of $10^{\circ} \mathrm{C} / \mathrm{min}$. The analytes passed through the column carried by helium (He), with an average speed of $20 \mathrm{~cm} / \mathrm{s}$. At the end, the detector (PFPD 5380, OI Analytical, College Station, TX, USA) worked at $250^{\circ} \mathrm{C}$.

The fermentative aroma compounds (higher alcohols, esters, fatty acids, etc.) of the resulting wines were evaluated by means of a gas chromatograph (HP 5890 Series II, Hewlett Packard, Palo Alto, California, Estados Unidos) coupled with a mass spectrometry detector (HP 5972 MSD, Hewlett Packard). The analysis was performed based on a previously reported methodology [37] with the following modifications [34]. First, samples needed to be prepared for the extraction: $10 \mathrm{~mL}$ of sample, $10 \mu \mathrm{L}$ of each internal standard, $2 \mathrm{~g}$ of sodium chloride $(\mathrm{NaCl})$, and $160 \mu \mathrm{L}$ of 1,1,2-trichlorotrifluoroethane (Freon 113) were added to a $15 \mathrm{~mL}$ tube. The internal standards were 2,6-dimethyl-5-hepten-2-ol (DMH, $1219 \mu \mathrm{g} / \mathrm{L}$ ) and isopropylbenzene $(268 \mu \mathrm{g} / \mathrm{L})$, and 1,1,2-trifluorotrichloroethane was the extraction reagent. Then, the solution was shaken for $20 \mathrm{~min}$ with an Intelli-Mixer (NeoLab) and was subsequently centrifuged at $3000 \mathrm{rpm}$ for $8 \mathrm{~min}$. The organic phase was removed with a glass pipette and dried with $50 \mathrm{mg}$ of $\mathrm{Na}_{2} \mathrm{SO}_{4}$ on glass wool. Then, $2 \mu \mathrm{l}$ of the extract was used for chromatographic analysis. The GC oven was equipped with a Gerstel MPS 2 Autosampler and CIS 3 cooled injection system. The sample was injected in splitless mode (initial temperature $30^{\circ} \mathrm{C}$, rate $12{ }^{\circ} \mathrm{C} / \mathrm{s}$ to $230^{\circ} \mathrm{C}$, held for $4 \mathrm{~min}$ ) into a VF-5MS capillary column $(60 \mathrm{~mm} \times 0.32 \mathrm{~mm} \times 1 \mu \mathrm{m}$; Varian, Steinheim, Germany), and helium was used as a carrier gas (flow of $1 \mathrm{~mL} / \mathrm{min}$ ). A precise temperature program was applied: an initial temperature of $40{ }^{\circ} \mathrm{C}$ was held for $5 \mathrm{~min}$, then raised to $125^{\circ} \mathrm{C}$ at $3{ }^{\circ} \mathrm{C} / \mathrm{min}$, and then raised again to $200{ }^{\circ} \mathrm{C}$ at $6{ }^{\circ} \mathrm{C} / \mathrm{min}$ and held for $14.2 \mathrm{~min}$. The working temperature of the MS detector was $180^{\circ} \mathrm{C}$. Mass spectral data were acquired in a range of mass to charge ratio $(\mathrm{m} / \mathrm{z})$ of 35 to 250 and used to derive concentration values.

\subsection{Statistical Analysis}

Statistical analysis was performed using RStudio v. 1.1.414 software (@ 2009-2016 RStudio Inc.). Parametric analysis of variance (ANOVA) was used when the assumptions of normal distribution and homogeneity of variances were satisfied (LSD.test function in agricolae package). Alternatively, in the case of non-normal distribution or heterogeneity of variances, non-parametric analysis was chosen (waerden.test function in agricolae package). Differences were considered significant at a $p$-value $<0.05$.

\section{Results}

\subsection{Fermentation Kinetics}

Figure 1 shows the fermentation curves of each strain under the two nutrient conditions. It is evident that the addition of nutrients promoted higher fermentative activity. AlphaTd showed the highest activity, while Prelude and Biodiva had similar behavior. The values of residual sugar in the resulting wines followed these differences (Table 1): only wines fermented with AlphaTd and added nutrients were able to almost finish the fermentation, with less than $3.27 \mathrm{~g} / \mathrm{L}$ of residual sugar on average. In the other cases, the amount of residual sugar varied from 17.49 to $67.15 \mathrm{~g} / \mathrm{L}$. Therefore, the range of ethanol produced ranged from 5.2\% to 9.2\%. AlphaTd, Biodiva and Prelude synthesized 6\%, 24\% and $30 \%$ more ethanol from fermentable sugars with nutrient suplementation than the regular controls. Acetic acid concentrations were less than $0.1 \mathrm{~g} / \mathrm{L}$ in all cases, even though high variability was evident in the fermentation performance. The content of malic acid after 15 days of fermentation was lower than the 
initial value in all cases, indicating malic acid degradation. The level of this degradation was moderate, with a rate ranging from $10.5 \%$ to $27.3 \%$, corresponding to a consumption of 0.23 and $0.60 \mathrm{~g} / \mathrm{L}$ of malic acid, respectively. The highest amount was consumed by AlphaTd under both nutrient conditions.

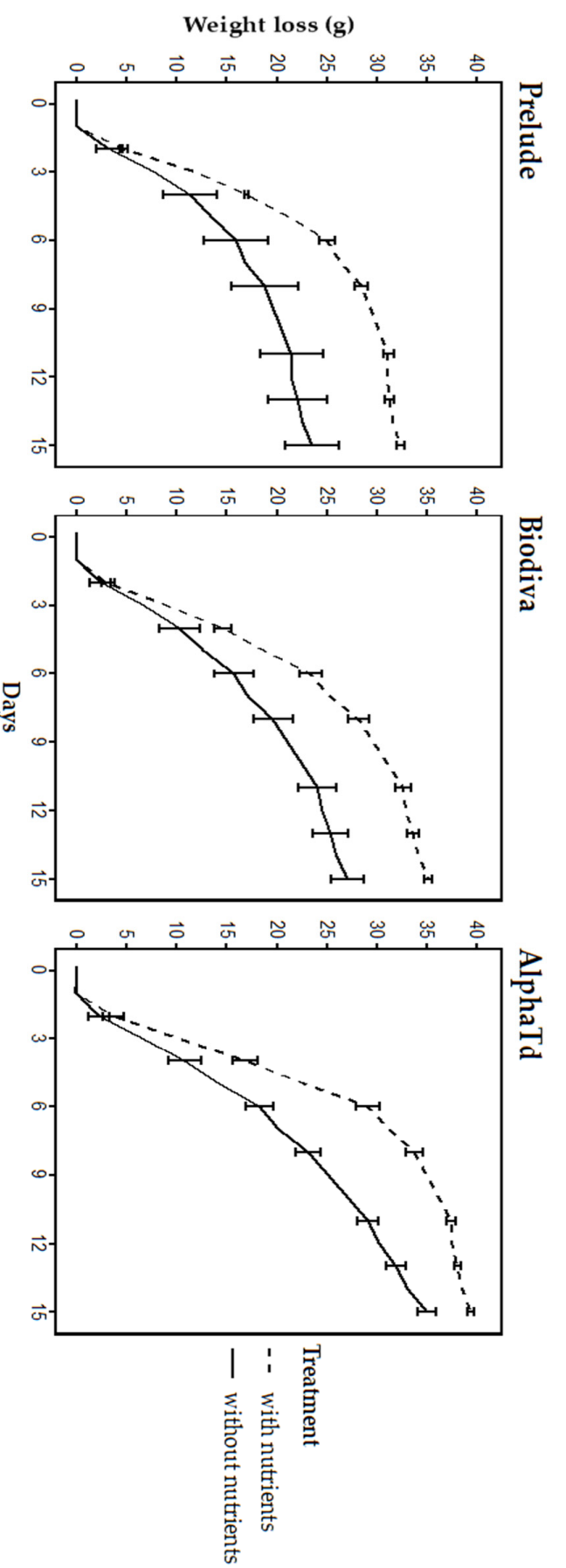

Figure 1. Fermentation kinetics of Prelude, Biodiva, and AlphaTd strains under the two nutrient conditions. Curves describe the loss of weight (g) throughout the 15 days of fermentation. Curves were plotted using the average values of triplicates; error bars represent standard deviations of each measurement. Solid lines represent fermentations conducted without the addition of nutrients; dashed lines represent fermentations with the addition of nutrients. 
Table 1. Main fermentation parameters of wines resulting from grape juice fermentation by T. delbrueckii strains Prelude, Biodiva, and AlphaTd, in single cultures and the statistical differences.

\begin{tabular}{ccccccc}
\hline \multirow{2}{*}{ Parameters } & \multicolumn{5}{c}{ Yeast Strains and Nutrient Conditions } \\
\cline { 2 - 7 } & Prelude & $\begin{array}{c}\text { Prelude }+ \\
\text { Nutrients }\end{array}$ & Biodiva & $\begin{array}{c}\text { Biodiva }+ \\
\text { Nutrients }\end{array}$ & AlphaTd & $\begin{array}{c}\text { Alpha Td + } \\
\text { Nutrients }\end{array}$ \\
\cline { 2 - 7 } & & & & & \\
Residual glucose & $22.28 \pm 4.62 \mathrm{a}$ & $9.49 \pm 0.81 \mathrm{c}$ & $14.89 \pm 1.84 \mathrm{~b}$ & $5.29 \pm 0.66 \mathrm{~d}$ & $3.10 \pm 0.35 \mathrm{e}$ & n.q. \\
(g/L) & & & & & & \\
Residual fructose & $44.87 \pm 5.11 \mathrm{a}$ & $24.05 \pm 1.29 \mathrm{~b}$ & $36.91 \pm 4.05 \mathrm{a}$ & $16.32 \pm 0.96 \mathrm{c}$ & $14.39 \pm 2.54 \mathrm{c}$ & $2.27 \pm 0.29 \mathrm{~d}$ \\
(g/L) & & & & & & \\
Ethanol (g/L) & $40.60 \pm 5.11 \mathrm{~d}$ & $57.92 \pm 0.99 \mathrm{c}$ & $48.35 \pm 2.95 \mathrm{~d}$ & $63.22 \pm 0.74 \mathrm{~b}$ & $65.57 \pm 1.26 \mathrm{~b}$ & $72.68 \pm 0.09 \mathrm{a}$ \\
Ethanol (\%) & $5.1 \pm 0.65$ & $7.3 \pm 0.13$ & $6.1 \pm 0.37$ & $8.0 \pm 0.09$ & $8.3 \pm 0.16$ & $9.2 \pm 0.01$ \\
Ethanol yield & $0.40 \pm 0.01 \mathrm{~d}$ & $0.43 \pm 0.00 \mathrm{c}$ & $0.41 \pm 0.00 \mathrm{~d}$ & $0.43 \pm 0.00 \mathrm{c}$ & $0.43 \pm 0.00 \mathrm{~b}$ & $0.44 \pm 0.00 \mathrm{a}$ \\
Acetic acid (g/L) & n.q. & n.q. & n.q. & n.q. & n.q. & n.q. \\
Malic acid (g/L) & $1.85 \pm 0.02 \mathrm{~b}$ & $1.78 \pm 0.01 \mathrm{~cd}$ & $1.95 \pm 0.01 \mathrm{a}$ & $1.82 \pm 0.01 \mathrm{bc}$ & $1.75 \pm 0.06 \mathrm{~d}$ & $1.60 \pm 0.03 \mathrm{e}$ \\
Lactic acid (g/L) & n.q. & n.q. & n.q. & n.q. & n.q. & n.q. \\
Citric acid (g/L) & $0.11 \pm 0.01 \mathrm{a}$ & $0.10 \pm 0.00 \mathrm{a}$ & $0.11 \pm 0.01 \mathrm{a}$ & $0.10 \pm 0.00 \mathrm{a}$ & $0.11 \pm 0.01 \mathrm{a}$ & $0.11 \pm 0.01 \mathrm{a}$ \\
Tartaric acid (g/L) & $2.20 \pm 0.00 \mathrm{a}$ & $2.22 \pm 0.01 \mathrm{a}$ & $2.21 \pm 0.00 \mathrm{a}$ & $2.24 \pm 0.02 \mathrm{a}$ & $2.22 \pm 0.00 \mathrm{a}$ & $2.24 \pm 0.02 \mathrm{a}$ \\
\hline
\end{tabular}

Significant differences $(p<0.05)$ are indicated with different letters. All values are averages of triplicates \pm standard deviation. n.q., not quantifiable.

\subsection{Production of Volatile Compounds}

Table 2 reports the concentrations of volatile compounds found in the resulting wines. Hydrogen sulfide was the only sulfur compound detected in the resulting wines, at concentrations ranging from 5.3 to $12.7 \mu \mathrm{g} / \mathrm{L}$. Fermentations carried out by AlphaTd produced the highest amounts, while Prelude and Biodiva produced non quantifiable concentrations fermented without nutrients. AlphaTd produced $29 \%$ more hydrogen sulfide in the presence of nutrients. 
Table 2. Volatile aroma compounds produced by three commercial strains of $T$. delbrueckii under two nutrient conditions.

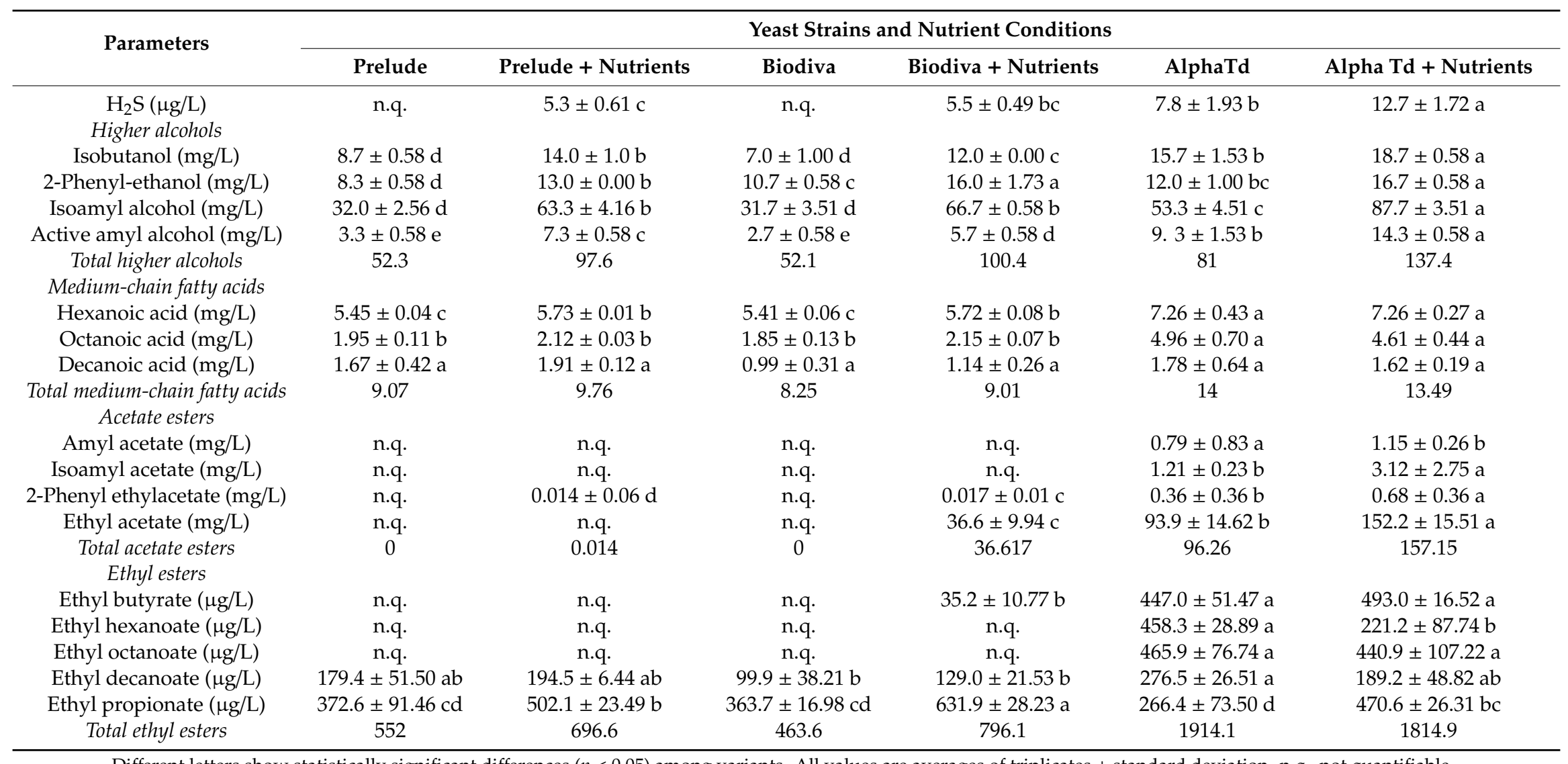

Different letters show statistically significant differences $(p<0.05)$ among variants. All values are averages of triplicates \pm standard deviation. n.q., not quantifiable. 
Regarding fermentative aroma compounds, the total concentrations of higher alcohols among the three strains tested varied from approximately 40 to $137 \mathrm{mg} / \mathrm{L}$. For all compounds, a higher fermentation intensity corresponded with a higher concentration, and under both nutrient conditions, the predominant higher alcohol was isoamyl alcohol, exceeding its sensory threshold $(30 \mathrm{mg} / \mathrm{L})$. AlphaTd, Biodiva and Prelude produced, respectively, 59\%, 52\% and 54\% more total higher alcohols for the trails enriched with nutrients. It is worth noting that all strains fermented with nutrients produced 2-phenylethanol above its odor threshold, in a range of 13.0-16.7 mg/L (Table 2). The concentrations of four volatile medium-chain fatty acids were investigated, and the results are reported in Table 2 . Except for decanoic acid, for which no significant differences were found among all strains and nutrient conditions, the AlphaTd strain was shown to be the highest producer of hexanoic and octanoic acids. Slight differences in total volatile medium-chain fatty acids were observed between the trials with added nutrients and the regular controls. The production of ester compounds seemed to be affected by the yeast strain and the nutrient condition. In fact, only AlphaTd produced hexyl acetate, isoamyl acetate, and amyl acetate, while Prelude and Biodiva produced very low concentrations of 2-phenylethyl acetate in fermentation with nutrients, during which Biodiva also produced ethyl acetate. In addition, it is worth mentioning the production of ethyl acetate by AlphaTd at higher concentrations. On the other hand, ethyl butyrate, ethyl hexanoate, and ethyl decanoate were produced only by AlphaTd under both nutrient conditions. The Prelude and Biodiva strains instead produced ethyl propionate and ethyl decanoate. AlphaTd did not increase the total ester concentration with nutrient addition, while Biodiva and Prelude increased the sum of total esters for the trials enriched with nutrients by $44 \%$ and $21 \%$, respectively.

\section{Discussion}

\subsection{Fermentation Parameters}

Supplementation with nutrients promotes fermentation activity, with a higher consumption of sugar and higher production of ethanol [38]. Thus, the role of nutrients in the stimulation of fermentation kinetics is confirmed for T. delbrueckii in this experiment. The ethanol yield can be considered to compare the fermentative power among the strains tested in this trial. A transformation ratio of $16.83 \mathrm{~g} / \mathrm{L}$ of sugar for $1 \% \mathrm{v} / \mathrm{v}$ of ethanol for S. cerevisiae $[39,40]$ is generally accepted. This means that a normal ethanol yield would be approximately $0.48 \mathrm{~g} / \mathrm{g}$, while the values obtained in this trial ranged from 0.40 to $0.44 \mathrm{~g} / \mathrm{g}$ (Table 1). These results agree with the low fermentative ability attributed to non-Saccharomyces yeasts [33]. The interesting aspect is the higher yield with the addition of nutrients. The same behavior has been described by other authors for T. delbrueckii [41] and other non-Saccharomyces yeast species [42], suggesting a role of nitrogen in the promotion of a higher rate of fermentation over other metabolic functions.

The low amount of acetic acid present in all wines, regardless of sugar consumption or nutrient conditions, is not surprising. In fact, the low production of acetic acid is one of the most interesting features of T. delbrueckii, widely reported in the literature even in association with S. cerevisiae [43]. Therefore, the application of T. delbrueckii in association with S. cerevisiae is an interesting oenological resource to keep the volatile acidity low [9].

Few wine yeast species have been studied for their ability to degrade malic acid. Among all non-Saccharomyces yeasts associated with winemaking, only Schizosaccharomyces pombe showed activity comparable to lactic acid bacteria $[44,45]$. On the other hand, Torulaspora delbrueckii has been described as only a moderate malic acid consumer. In this study, malic acid was consumed by all strains with a degradation rate ranging from $10.5 \%$ to $27.3 \%$. These results are consistent with other findings from the literature [26,46]. Additionally, in this study, nutrient supplementation stimulated malic acid degradation by all strains in 9\% (AlphaTd), 7\% (Biodiva) and 4\% (Prelude) respectively (Table 1). The malic acid degradation can be variable depending on the fermentation conditions, as 
demonstrated by the fact that the same strain used in this study showed no malic acid degradation in lychee must fermentation [47].

\subsection{Hydrogen Sulfide Production}

Hydrogen sulfide formation in wines is undesirable due to its "rotten egg" and "cabbage" odor. Different odor thresholds have been reported in the literature. Some authors reported an odor threshold of 1-1.6 ng/L [48,49], while others reported a range of 11-80 $\mu \mathrm{g} / \mathrm{L}$ [50-52]. Based on the different odor thresholds, the concentrations of hydrogen sulfide found in this experiment could be considered either highly detrimental for wine quality or still quite acceptable. The lack of nitrogen availability is considered one of the main causes of $\mathrm{H}_{2} \mathrm{~S}$ production by yeasts [53]; however, in this case, the fermentations with higher nitrogen availability resulted in a higher content of hydrogen sulfide (Table 2). Although the production of $\mathrm{H}_{2} \mathrm{~S}$ as a result of supplementing must with nitrogenous compounds has been described $[49,54,55]$, in this trial this scenario does not explain why $\mathrm{H}_{2} \mathrm{~S}$ was also found in slightly increased amounts in wines fermented with AlphaTd with and without the addition of nutrients. It could be hypothesized that high sulfite reductase activity is the reason for $\mathrm{H}_{2} \mathrm{~S}$ production, through a mechanism previously described in the literature $[53,56]$. This hypothesis is consistent with the high sulfite reductase activity reported for many $T$. delbrueckii strains [6,57]. Furthermore, it can be assumed that this strain generally has a relatively high requirement for nutrients. Finally, the production of hydrogen sulfide from cysteine degradation cannot be excluded since it has been demonstrated that T. delbrueckii has high $\beta$-lyase activity and carries a full-length copy of the IRC7 gene [25]. IRC7 has been reported as the gene that encodes the enzymes that produce 4-methyl-4-sulfanylpentan-2-one from Cysteine-4-methyl-4-sulfanylpentan-2-one [8].

\subsection{Fermentative Aroma Compound Production}

Non-Saccharomyces yeasts are interesting for their ability to improve wine aroma complexity $[8,33,58]$. The total concentrations of higher alcohols observed were lower than the concentrations usually found in wines, i.e., $140-420 \mathrm{mg} / \mathrm{L}[59,60]$, but consistent with previous findings from the literature $[17,21,34]$. Non-Saccharomyces yeasts are usually indicated as being lower producers of higher alcohols than S. cerevisiae $[1,7,33]$. In particular, T. delbrueckii has been described as being able to lower the total amount of higher alcohols in sequential fermentation with S. cerevisiae. This effect can result in a more positive score in sensorial analysis compared with S. cerevisiae in pure fermentation due to the greater impact of varietal aromas that are not masked by higher alcohols $[8,25]$. Other studies performed with different $T$. delbrueckii strains showed the same pattern of higher alcohol production $[17,61]$. This aspect highlights the hypothesis that there is common behavior within the T. delbrueckii species, confirming the possibility of using aroma production profiles as species indicators. In this study, all strains showed increased production of higher alcohols in fermentations with added nutrients. However, the opposite behavior has often been reported, with lower production of higher alcohols under the condition of higher nitrogen availability $[62,63]$. Some authors have suggested that higher alcohols are produced in greater amounts when there is a higher demand of nitrogen to sustain protein synthesis and population growth [7]. This explanation could also be applicable to the results of this trial. In fermentation with higher nitrogen availability, yeasts might have produced more higher alcohols in response to higher fermentation activity or a larger population size. The strain variability in the production of higher alcohols reported in this study agrees with other studies, where differences up to $38 \%$ were observed depending on the studied T. delbrueckii strain in higher alcohols, such as 1 butanol [26]. Only a few studies reported concentration values of medium-chain fatty acids (MCFAs) produced by $T$. delbrueckii in pure fermentations and, in general, the concentration of each compound did not exceed 1 $\mathrm{mg} / \mathrm{L}[17,26]$. In this trial, however, the three strains of T. delbrueckii produced higher concentrations of MCFAs compared to those reported in the literature. On the other hand, isovaleric acid resulted in nonquantifiable amounts for all strains (data not shown). However, other studies reported that some strains of T. delbrueckii were high producers of this compound [26]. Considering each fatty acid 
individually, all concentrations were below the sensory thresholds; however, the total concentrations were close to $10 \mathrm{mg} / \mathrm{L}$ for Prelude and Biodiva, while AlphaTd produced almost $14 \mathrm{mg} / \mathrm{L}$ of MCFAs. A direct influence of nitrogen availability on the production of MCFAs has been described in the literature, with a higher nitrogen content promoting a higher production of these compounds in S. cerevisiae [64,65]. In this trial, only the production of hexanoic acid, and only by Prelude and Biodiva strains, was shown to be influenced by the addition of commercial nutrient preparations. Therefore, we can deduce that the production of MCFAs by T. delbrueckii is influenced either by the yeast strain, as in the case of octanoic acid, or by the nutrient availability, as in the case of hexanoic acid (Table 2).

The variability registered in the production of esters was high among the three strains; in particular, many compounds were produced only by the AlphaTd strain. The presence of esters in wines is desired for their fruity notes; however, in this case, the production of high amounts of ethyl acetate, which can be unpleasant at concentrations above $100 \mathrm{mg} / \mathrm{L}$ [66], should be noted. This behavior has never been reported in the literature; on the contrary, T. delbrueckii has always been described positively for its high fermentation purity thanks to its low production of acetic acid and ethyl acetate $[21,26]$. On the other hand, 2-phenylethyl acetate and isoamyl acetate were also produced in high amounts, and these compounds are known to impart very pleasant fruity and floral notes, in particular of banana and rose; also, for these compounds, the concentrations found in this trial were higher than those reported in the literature for fermentations by T. delbrueckii strains in single cultures $[26,28,67]$. For all acetate esters, AlphaTd showed a higher concentration in fermentations enriched with nutrients. This phenomenon is well described in the literature for S. cerevisiae [64,68], as the addition of nutrients likely had a direct stimulating effect on ester production. In this regard, the lack of acetate ester production by Prelude and Biodiva strains could be explained by low fermentative activity and thus low enzymatic activity. Considering ethyl esters, AlphaTd was the only producer of ethyl butyrate, ethyl hexanoate, and ethyl octanoate, while all three strains under both nutrient conditions produced ethyl decanoate and ethyl propionate. It is known that ethyl ester production is dependent on the availability of corresponding fatty acid precursors. Therefore, any increase in production as a result of higher nitrogen availability should be ascribed to an increased synthesis of fatty acids [69,70], and in this trial, AlphaTd confirmed this dependency.

As it is not possible to compare the results with previous studies regarding Torulaspora delbrueckii and nutrient supplementation influence over aroma composition., further studies should be performed in the future using deuterated internal and/or external standards to validate the commented results.

\section{Conclusions}

T. delbrueckii's production of aroma compounds during alcoholic fermentation is subject to complex regulation. Both strain diversity and the availability of nutrients lead to significant differences in the production of volatile aroma compounds. The addition of nutrients increases the speed of fermentation for all strains, as well as ethanol production, malic acid degradation, and the formation of most volatile aroma compounds. Alpha strain produced higher concentrations of ethanol, higher alcohols, medium-chain fatty acids and esters than the other studied strains while also degrading more malic acid. The addition of nutrients increased the levels of higher alcohols and esters significantly for all the T. delbrueckii studied strains, while the increase in medium-chain fatty acids was moderate.

Author Contributions: D.R., S.B. (Santiago Benito) and D.M. developed the experimental design; D.M. and S.B. (Santiago Benito) performed the vinifications; D.M. and S.B. (Santiago Benito) performed the formal data analysis and supervised the project; D.M., S.B. (Santiago Benito), and D.R. wrote the article; S.B. (Silvia Brezina), S.F., and B.B. performed gas chromatographic analysis; H.S. performed HPLC analysis. All authors discussed the results and contributed to the final manuscript. All authors have read and agreed to the published version of the manuscript

Funding: Funding for Santiago Benito was provided by Ossian Vides y Vinos S. L under the framework of project FPA1720300120 (Centre for the Development of Industrial Technology (CDTI), Spain).

Conflicts of Interest: The authors declare no conflict of interest. 


\section{References}

1. Jolly, N.P.; Varela, C.; Pretorius, I.S. Not your ordinary yeast: Non-Saccharomyces yeasts in wine production uncovered. FEMS Yeast Res. 2014, 14, 215-217. [CrossRef] [PubMed]

2. Porter, T.J.; Divol, B.; Setati, M.E. Lachancea yeast species: Origin, biochemical characteristics and oenological significance. Food Res. Int. 2019, 119, 378-389. [CrossRef] [PubMed]

3. Benito, A.; Calderón, F.; Benito, S. The Influence of Non-Saccharomyces Species on Wine Fermentation Quality Parameters. Fermentation 2019, 5, 54. [CrossRef]

4. Viana, F.; Gil, J.V.; Genovés, S.; Vallés, S.; Manzanares, P. Rational selection of non-Saccharomyces wine yeasts for mixed starters based on ester formation and enological traits. Food Microbiol. 2008, 25, 778-785. [CrossRef] [PubMed]

5. Zott, K.; Thibon, C.; Bely, M.; Lonvaud-Funel, A.; Dubourdieu, D.; Masneuf-Pomarede, I. The grape must non-Saccharomyces microbial community: Impact on volatile thiol release. Int. J. Food Microbiol. 2011, 151, 210-215. [CrossRef]

6. Escribano, R.; González-Arenzana, L.; Garijo, P.; Berlanas, C.; López-Alfaro, I.; López, R.; Gutiérrez, A.R.; Santamaría, P. Screening of enzymatic activities within different enological non-Saccharomyces yeasts. J. Food Sci. Technol. 2017, 54, 1555-1564. [CrossRef]

7. González, B.; Vázquez, J.; Morcillo-Parra, M.Á.; Mas, A.; Torija, M.J.; Beltran, G. The production of aromatic alcohols in non-Saccharomyces wine yeast is modulated by nutrient availability. Food Microbiol. 2018, 74, 64-74. [CrossRef]

8. Ruiz, J.; Kiene, F.; Belda, I.; Fracassetti, D.; Marquina, D.; Navascués, E.; Calderón, F.; Benito, A.; Rauhut, D.; Santos, A.; et al. Effects on varietal aromas during wine making: A review of the impact of varietal aromas on the flavor of wine. Appl. Microbiol. Biotechnol. 2019, 103, 7425-7450. [CrossRef]

9. Bely, M.; Stoeckle, P.; Masneuf-Pomarède, I.; Dubourdieu, D. Impact of mixed Torulaspora delbrueckii-Saccharomyces cerevisiae culture on high-sugar fermentation. Int. J. Food Microbiol. 2008, 122, 312-320. [CrossRef]

10. Benito, A.; Calderón, F.; Benito, S. Combined use of S. pombe and L. thermotolerans in winemaking. Beneficial effects determined through the study of wines' analytical characteristics. Molecules 2016, 21, 1744. [CrossRef]

11. Gobbi, M.; Comitini, F.; Domizio, P.; Romani, C.; Lencioni, L.; Mannazzu, I.; Ciani, M. Lachancea thermotolerans and Saccharomyces cerevisiae in simultaneous and sequential co-fermentation: A strategy to enhance acidity and improve the overall quality of wine. Food Microbiol. 2013, 33, 271-281. [CrossRef]

12. Domizio, P.; Liu, Y.; Bisson, L.F.; Barile, D. Use of non-Saccharomyces wine yeasts as novel sources of mannoproteins in wine. Food Microbiol. 2014, 43, 5-15. [CrossRef] [PubMed]

13. Albertin, W.; Chasseriaud, L.; Comte, G.; Panfili, A.; Delcamp, A.; Salin, F.; Marullo, P.; Bely, M. Winemaking and bioprocesses strongly shaped the genetic diversity of the ubiquitous yeast Torulaspora delbrueckii. PLoS ONE 2014, 9, e94246. [CrossRef] [PubMed]

14. Benito, S. The impact of Torulaspora delbrueckii yeast in winemaking. Appl. Microbiol. Biotechnol. 2018, 102, 3081-3094. [CrossRef] [PubMed]

15. Ramírez, M.; Velázquez, R. The yeast Torulaspora delbrueckii: An interesting but difficult-to-use tool for winemaking. Fermentation 2018, 4, 94. [CrossRef]

16. Roudil, L.; Russo, P.; Berbegal, C.; Albertin, W.; Spano, G.; Capozzi, V. Non-Saccharomyces Commercial Starter Cultures: Scientific Trends, Recent Patents and Innovation in the Wine Sector. Recent Pat. Food Nutr. Agric. 2019, 10, 1-13. [CrossRef] [PubMed]

17. Renault, P.; Miot-Sertier, C.; Marullo, P.; Hernández-Orte, P.; Lagarrigue, L.; Lonvaud-Funel, A.; Bely, M. Genetic characterization and phenotypic variability in Torulaspora delbrueckii species: Potential applications in the wine industry. Int. J. Food Microbiol. 2009, 134, 201-210. [CrossRef]

18. van Breda, V.; Jolly, N.; van Wyk, J. Characterisation of commercial and natural Torulaspora delbrueckii wine yeast strains. Int. J. Food Microbiol. 2013, 163, 80-88. [CrossRef]

19. Escribano-Viana, R.; González-Arenzana, L.; Portu, J.; Garijo, P.; López-Alfaro, I.; López, R.; Santamaría, P.; Gutiérrez, A.R. Wine aroma evolution throughout alcoholic fermentation sequentially inoculated with non-Saccharomyces/Saccharomyces yeasts. Food Res. Int. 2018, 112, 17-24. [CrossRef]

20. Benito, S. The impacts of Lachancea thermotolerans yeast strains on winemaking. Appl. Microbiol. Biotechnol. 2018, 102, 6775-6790. [CrossRef] 
21. Belda, I.; Navascués, E.; Marquina, D.; Santos, A.; Calderon, F.; Benito, S. Dynamic analysis of physiological properties of Torulaspora delbrueckii in wine fermentations and its incidence on wine quality. Appl. Microbiol. Biotechnol. 2015, 99, 1911-1922. [CrossRef]

22. du Plessis, H.; du Toit, M.; Nieuwoudt, H.; van der Rijst, M.; Kidd, M.; Jolly, N. Effect of Saccharomyces, Non-Saccharomyces Yeasts and Malolactic Fermentation Strategies on Fermentation Kinetics and Flavor of Shiraz Wines. Fermentation 2017, 3, 64. [CrossRef]

23. García, M.; Apolinar-Valiente, R.; Williams, P.; Esteve-Zarzoso, B.; Arroyo, T.; Crespo, J.; Doco, T. Polysaccharides and Oligosaccharides Produced on Malvar Wines Elaborated with Torulaspora delbrueckii CLI 918 and Saccharomyces cerevisiae CLI 889 Native Yeasts from D.O. "vinos de Madrid.". J. Agric. Food Chem. 2017, 65, 6656-6664.

24. Ciani, M.; Maccarelli, F. Oenological properties of non-Saccharomyces yeasts associated with wine-making. World J. Microbiol. Biotechnol. 1998, 14, 199-203. [CrossRef]

25. Belda, I.; Ruiz, J.; Beisert, B.; Navascués, E.; Marquina, D.; Calderón, F.; Rauhut, D.; Benito, S.; Santos, A. Influence of Torulaspora delbrueckii in varietal thiol (3-SH and 4-MSP) release in wine sequential fermentations. Int. J. Food Microbiol. 2017, 257, 183-191. [CrossRef] [PubMed]

26. Escribano, R.; González-Arenzana, L.; Portu, J.; Garijo, P.; López-Alfaro, I.; López, R.; Santamaría, P.; Gutiérrez, A.R. Wine aromatic compound production and fermentative behaviour within different non-Saccharomyces species and clones. J. Appl. Microbiol. 2018, 124, 1521-1531. [CrossRef] [PubMed]

27. Plata, C.; Millán, C.; Mauricio, J.C.; Ortega, J.M. Formation of ethyl acetate and isoamyl acetate by various species of wine yeasts. Food Microbiol. 2003, 20, 217-224. [CrossRef]

28. Renault, P.; Coulon, J.; de Revel, G.; Barbe, J.C.; Bely, M. Increase of fruity aroma during mixed T. delbrueckii/S. cerevisiae wine fermentation is linked to specific esters enhancement. Int. J. Food Microbiol. 2015, 207, 40-48. [CrossRef]

29. King, A.; Dickinson, J.R. Biotransformation of monoterpene alcohols by Saccharomyces cerevisiae, Torulaspora delbrueckii and Kluyveromyces lactis. Yeast 2000, 16, 499-506. [CrossRef]

30. Jenko, M.; Čuš, F. The Influence of Yeast Strains on the Composition and Sensory Quality of Gewürztraminer Wine. Food Technol. Biotechnol. 2013, 51, 547-553.

31. Roncoroni, M.; Santiago, M.; Hooks, D.O.; Moroney, S.; Harsch, M.J.; Lee, S.A.; Richards, K.D.; Nicolau, L.; Gardner, R.C. The yeast IRC7 gene encodes a $\beta$-lyase responsible for production of the varietal thiol 4-mercapto-4-methylpentan-2-one in wine. Food Microbiol. 2011, 28, 926-935. [CrossRef] [PubMed]

32. Renault, P.; Coulon, J.; Moine, V.; Thibon, C.; Bely, M. Enhanced 3-sulfanylhexan-1-ol production in sequential mixed fermentation with Torulaspora delbrueckii/Saccharomyces cerevisiae reveals a situation of synergistic interaction between two industrial strains. Front. Microbiol. 2016, 7, 293. [CrossRef] [PubMed]

33. Benito, S.; Hofmann, T.; Laier, M.; Lochbühler, B.; Schüttler, A.; Ebert, K.; Fritsch, S.; Röcker, J.; Rauhut, D. Effect on quality and composition of Riesling wines fermented by sequential inoculation with non-Saccharomyces and Saccharomyces cerevisiae. Eur. Food Res. Technol. 2015, 241,707-717. [CrossRef]

34. Dutraive, O.; Benito, S.; Fritsch, S.; Beisert, B.; Patz, C.-D.; Rauhut, D. Effect of Sequential Inoculation with Non-Saccharomyces and Saccharomyces Yeasts on Riesling Wine Chemical Composition. Fermentation 2019, 5, 79. [CrossRef]

35. Schneider, A.; Gerbi, V.; Redoglia, M. A Rapid HPLC Method for Separation and Determination of Major Organic Acids in Grape Musts and Wines. Am. J. Enol. Vitic. 1987, 38, 151-155.

36. Irmler, S.; Schäfer, H.; Beisert, B.; Rauhut, D.; Berthoud, H. Identification and characterization of a strain-dependent cystathionine $\beta / \gamma$-lyase in Lactobacillus casei potentially involved in cysteine biosynthesis. FEMS Microbiol. Lett. 2009, 295, 67-76. [CrossRef]

37. Rapp, A.; Yavas, I.; Hastrich, H. Easy and Fast Enrichment ("Kaltronmethod") and Quantitative Determination of Wine Volatiles with Capillary-Gaschromatography. Dtsch. Lebensm. Rundsch. 1994, 90, 171-174.

38. Gobert, A.; Tourdot-Maréchal, R.; Morge, C.; Sparrow, C.; Liu, Y.; Quintanilla-Casas, B.; Vichi, S.; Alexandre, H. Non-Saccharomyces Yeasts nitrogen source preferences: Impact on sequential fermentation and wine volatile compounds profile. Front. Microbiol. 2017, 8, 2175. [CrossRef]

39. Ciani, M.; Morales, P.; Comitini, F.; Tronchoni, J.; Canonico, L.; Curiel, J.A.; Oro, L.; Rodrigues, A.J.; Gonzalez, R. Non-conventional yeast species for lowering ethanol content of wines. Front. Microbiol. 2016, 7, 642. [CrossRef] 
40. Pascual, O.; Pons-Mercadé, P.; Gombau, J.; Ortiz-Julien, A.; Heras, J.M.; Fort, F.; Canals, J.M.; Zamora, F. Study of the effectiveness of a strain of Saccharomyces cerevisiae selected for the production of wines with higher acidity and lower alcoholic strength. BIO Web Conf. 2017, 9, 02002. [CrossRef]

41. Taillandier, P.; Lai, Q.P.; Julien-Ortiz, A.; Brandam, C. Interactions between Torulaspora delbrueckii and Saccharomyces cerevisiae in wine fermentation: Influence of inoculation and nitrogen content. World J. Microbiol. Biotechnol. 2014, 30, 1959-1967. [CrossRef] [PubMed]

42. Rodrigues, A.J.; Raimbourg, T.; Gonzalez, R.; Morales, P. Environmental factors influencing the efficacy of different yeast strains for alcohol level reduction in wine by respiration. LWT Food Sci. Technol. 2016, 65, 1038-1043. [CrossRef]

43. Ciani, M.; Beco, L.; Comitini, F. Fermentation behaviour and metabolic interactions of multistarter wine yeast fermentations. Int. J. Food Microbiol. 2006, 108, 239-245. [CrossRef] [PubMed]

44. Minnaar, P.P.; Jolly, N.P.; Paulsen, V.; Du Plessis, H.W.; Van Der Rijst, M. Schizosaccharomyces pombe and Saccharomyces cerevisiae yeasts in sequential fermentations: Effect on phenolic acids of fermented Kei-apple (Dovyalis caffra L.) juice. Int. J. Food Microbiol. 2017, 257, 232-237. [CrossRef]

45. Benito, S. The impacts of Schizosaccharomyces on winemaking. Appl. Microbiol. Biotechnol. 2019, 257, $232-237$. [CrossRef]

46. du Plessis, H.W.; du Toit, M.; Hoff, J.W.; Hart, R.S.; Ndimba, B.K.; Jolly, N.P. Characterisation of non-Saccharomyces yeasts using different methodologies and evaluation of their compatibility with malolactic fermentation. S. Afr. J. Enol. Vitic. 2017, 38, 46-63. [CrossRef]

47. Chen, D.; Yap, Z.Y.; Liu, S.Q. Evaluation of the performance of Torulaspora delbrueckii, Williopsis saturnus, and Kluyveromyces lactis in lychee wine fermentation. Int. J. Food Microbiol. 2015, 206, 45-50. [CrossRef]

48. Mestres, M.; Busto, O.; Guasch, J. Analysis of organic sulfur compounds in wine aroma. J. Chromatogr. A 2000, 881, 569-581. [CrossRef]

49. Ugliano, M.; Kolouchova, R.; Henschke, P.A. Occurrence of hydrogen sulfide in wine and in fermentation: Influence of yeast strain and supplementation of yeast available nitrogen. J. Ind. Microbiol. Biotechnol. 2011, 38, 423-429. [CrossRef]

50. Mendes-Ferreira, A.; Mendes-Faia, A.; Leão, C. Survey of hydrogen sulphide production by wine yeasts. J. Food Prot. 2002, 65, 1033-1037. [CrossRef]

51. Rauhut, D. Usage and formation of sulphur compounds. In Biology of Microorganisms on Grapes, in Must and in Wine; Springer: Berlin/Heidelberg, Germany, 2017; ISBN 9783319600215.

52. Sutherland, C.M.; Henschke, P.A.; Langridge, P.; De Barros Lopes, M. Subunit and cofactor binding of Saccharomyces cerevisiae sulfite reductase-Towards developing wine yeast with lowered ability to produce hydrogen sulfide. Aust. J. Grape Wine Res. 2003, 9, 186-193. [CrossRef]

53. Jiranek, V.; Langridge, P.; Henschke, P.A. Regulation of hydrogen sulfide liberation in wine-producing Saccharomyces cerevisiae strains by assimilable nitrogen. Appl. Environ. Microbiol. 1995, 61, 461-467. [CrossRef] [PubMed]

54. Mendes-Ferreira, A.; Barbosa, C.; Falco, V.; Leão, C.; Mendes-Faia, A. The production of hydrogen sulphide and other aroma compounds by wine strains of Saccharomyces cerevisiae in synthetic media with different nitrogen concentrations. J. Ind. Microbiol. Biotechnol. 2009, 36, 571-583. [CrossRef] [PubMed]

55. Ugliano, M.; Fedrizzi, B.; Siebert, T.; Travis, B.; Magno, F.; Versini, G.; Henschke, P.A. Effect of nitrogen supplementation and Saccharomyces species on hydrogen sulfide and other volatile sulfur compounds in Shiraz fermentation and wine. J. Agric. Food Chem. 2009, 57, 4948-4955. [CrossRef] [PubMed]

56. Jiranek, V.; Langridge, P.; Henschke, P.A. Determination of sulphite reductase activity and its response to assimilable nitrogen status in a commercial Saccharomyces cerevisiae wine yeast. J. Appl. Bacteriol. 1996, 81, 329-336. [CrossRef]

57. Ciani, M.; Comitini, F. Non-Saccharomyces wine yeasts have a promising role in biotechnological approaches to winemaking. Ann. Microbiol. 2011, 61, 25-32. [CrossRef]

58. Padilla, B.; Gil, J.V.; Manzanares, P. Past and future of non-Saccharomyces yeasts: From spoilage microorganisms to biotechnological tools for improving wine aroma complexity. Front. Microbiol. 2016, 7, 411. [CrossRef]

59. Ebeler, S.E. Analytical chemistry: Unlocking the secrets of wine flavor. Food Rev. Int. 2001, 17, 45-64. [CrossRef] 
60. Ruiz, J.; Belda, I.; Beisert, B.; Navascués, E.; Marquina, D.; Calderón, F.; Rauhut, D.; Santos, A.; Benito, S. Analytical impact of Metschnikowia pulcherrima in the volatile profile of Verdejo white wines. Appl. Microbiol. Biotechnol. 2018, 102, 8501-8509. [CrossRef]

61. Canonico, L.; Comitini, F.; Ciani, M. Torulaspora delbrueckii for secondary fermentation in sparkling wine production. Food Microbiol. 2018, 74, 100-106. [CrossRef]

62. Beltran, G.; Esteve-Zarzoso, B.; Rozès, N.; Mas, A.; Guillamón, J.M. Influence of the timing of nitrogen additions during synthetic grape must fermentations on fermentation kinetics and nitrogen consumption. J. Agric. Food Chem. 2005, 53, 996-1002. [CrossRef] [PubMed]

63. Carrau, F.M.; Medina, K.; Farina, L.; Boido, E.; Henschke, P.A.; Dellacassa, E. Production of fermentation aroma compounds by Saccharomyces cerevisiae wine yeasts: Effects of yeast assimilable nitrogen on two model strains. FEMS Yeast Res. 2008, 8, 1196-1207. [CrossRef] [PubMed]

64. Torrea, D.; Varela, C.; Ugliano, M.; Ancin-Azpilicueta, C.; Leigh Francis, I.; Henschke, P.A. Comparison of inorganic and organic nitrogen supplementation of grape juice-Effect on volatile composition and aroma profile of a Chardonnay wine fermented with Saccharomyces cerevisiae yeast. Food Chem. 2011, 127, 1072-1083. [CrossRef] [PubMed]

65. Vilanova, M.; Siebert, T.E.; Varela, C.; Pretorius, I.S.; Henschke, P.A. Effect of ammonium nitrogen supplementation of grape juice on wine volatiles and non-volatiles composition of the aromatic grape variety Albariño. Food Chem. 2012, 133, 124-131. [CrossRef]

66. Sumby, K.M.; Grbin, P.R.; Jiranek, V. Microbial modulation of aromatic esters in wine: Current knowledge and future prospects. Food Chem. 2010, 121, 1-16. [CrossRef]

67. Sadoudi, M.; Tourdot-Maréchal, R.; Rousseaux, S.; Steyer, D.; Gallardo-Chacón, J.J.; Ballester, J.; Vichi, S.; Guérin-Schneider, R.; Caixach, J.; Alexandre, H. Yeast-yeast interactions revealed by aromatic profile analysis of Sauvignon Blanc wine fermented by single or co-culture of non-Saccharomyces and Saccharomyces yeasts. Food Microbiol. 2012, 32, 243-253. [CrossRef]

68. Vilanova, M.; Ugliano, M.; Varela, C.; Siebert, T.; Pretorius, I.S.; Henschke, P.A. Assimilable nitrogen utilisation and production of volatile and non-volatile compounds in chemically defined medium by Saccharomyces cerevisiae wine yeasts. Appl. Microbiol. Biotechnol. 2007, 77, 145-157. [CrossRef]

69. Garde-Cerdán, T.; Ancín-Azpilicueta, C. Effect of the addition of different quantities of amino acids to nitrogen-deficient must on the formation of esters, alcohols, and acids during wine alcoholic fermentation. LWT Food Sci. Technol. 2008, 41, 501-510. [CrossRef]

70. Saerens, S.M.G.; Delvaux, F.R.; Verstrepen, K.J.; Thevelein, J.M. Production and biological function of volatile esters in Saccharomyces cerevisiae. Microb. Biotechnol. 2010, 3, 165-177. [CrossRef] 